Article

\title{
Chemical Composition of Essential Oils from Leaves and Fruits of Juniperus foetidissima and Their Attractancy and Toxicity to Two Economically Important Tephritid Fruit Fly Species, Ceratitis capitata and Anastrepha suspensa
}

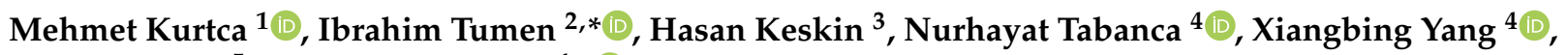 \\ Betul Demirci ${ }^{5}$ and Paul E. Kendra $4, *$ (D) \\ 1 Department of Chemistry, Faculty of Science, Selcuk University, 42130 Konya, Turkey; \\ mehmet.kurtca@selcuk.edu.tr \\ 2 Faculty of Health Sciences, Bandirma Onyedi Eylul University, 10200 Bandirma, Turkey \\ 3 Department of Forest Products Chemistry, Faculty of Forestry, Bartin University, 74100 Bartin, Turkey; \\ hkeskin@bartin.edu.tr \\ 4 United States Department of Agriculture-Agricultural Research Service (USDA-ARS), Subtropical \\ Horticulture Research Station (SHRS), 13601 Old Cutler Rd., Miami, FL 33158, USA; \\ nurhayat.tabanca@usda.gov (N.T.); xiangbing.yang@usda.gov (X.Y.) \\ check for \\ updates \\ 5 Department of Pharmacognosy, Faculty of Pharmacy, Anadolu University, 26470 Eskisehir, Turkey; \\ betuldemirci@gmail.com \\ * Correspondence: tumen@bandirma.edu.tr (I.T.); paul.kendra@usda.gov (P.E.K.)
}

Citation: Kurtca, M.; Tumen, I.; Keskin, H.; Tabanca, N.; Yang, X.; Demirci, B.; Kendra, P.E. Chemical Composition of Essential Oils from Leaves and Fruits of Juniperus foetidissima and Their Attractancy and Toxicity to Two Economically Important Tephritid Fruit Fly Species, Ceratitis capitata and Anastrepha suspensa. Molecules 2021, 26, 7504. https://doi.org/10.3390/ molecules26247504

Academic Editor: Luca Valgimigli

Received: 16 November 2021 Accepted: 8 December 2021 Published: 11 December 2021

Publisher's Note: MDPI stays neutral with regard to jurisdictional claims in published maps and institutional affiliations.

Copyright: (C) 2021 by the authors Licensee MDPI, Basel, Switzerland. This article is an open access article distributed under the terms and conditions of the Creative Commons Attribution (CC BY) license (https:/ / creativecommons.org/licenses/by/ $4.0 /)$.

Abstract: The present study analyzed the chemical composition of Juniperus foetidissima Willd. essential oils (EOs) and evaluated their attractancy and toxicity to two agriculturally important tephritid fruit flies. The composition of hydrodistilled EOs obtained from leaves (JFLEO) and fruits (JFFEO) of J. foetidissima was analyzed by GC-FID and GC-MS. The main compounds were $\alpha$-pinene (45\%) and cedrol (18\%) in the JFLEO and $\alpha$-pinene (42\%), $\alpha$-thujone $(12 \%)$, and $\beta$-thujone $(25 \%)$ in the JFFEO. In behavioral bioassays of the male Mediterranean fruit fly, Ceratitis capitata (Wiedemann), both JFLEO and JFFEO showed strong attraction comparable to that observed with two positive controls, Melaleuca alternifolia and Tetradenia riparia EOs. In topical bioassays of the female Caribbean fruit fly, Anastrepha suspensa (Loew), the toxicity of JFFEO was two-fold higher than that of JFLEO, with the $\mathrm{LD}_{50}$ values being 10.46 and $22.07 \mu \mathrm{g} / \mu \mathrm{L}$, respectively. This could be due to differences in chemical components between JFLEO and JFFEO. The JFFEO was dominated by $48 \%$ monoterpene hydrocarbons (MH) and 46\% oxygenated monoterpenes (OM), while JFLEO consisted of 57\% $\mathrm{MH}$, $18 \% \mathrm{OM}$, and $20 \%$ oxygenated sesquiterpenes (OS). This is the first study to evaluate the attractancy and toxicity of $J$. foetidissima EOs to tephritid fruit flies. Our results indicate that JFFEO has the potential for application to the management of pest tephritid species, and further investigation is warranted.

Keywords: juniper oil; Cupressaceae; $\alpha$-pinene; $\alpha$-thujone; $\beta$-thujone; cedrol; Mediterranean fruit fly; medfly; Caribbean fruit fly

\section{Introduction}

Resistance to chemical pesticides and the negative effects of chemical residues on the environment, non-target organisms, and human health have led to an urgent need for more environmentally sound strategies for pest management [1-3]. Essential oils (EOs) and their rich source of bioactive compounds are considered one of the best resources for the development of alternative insect control agents [1,2,4,5]. The Mediterranean fruit fly or medfly, Ceratitis capitata (Wiedemann) (Diptera: Tephritidae) is one of the most destructive and economically important agricultural pests worldwide. The Caribbean 
fruit fly, Anastrepha suspensa (Loew), is found in Cuba, Jamaica, Hispaniola, Puerto Rico, and Florida, USA, where it is a quarantine pest of citrus and a production pest of many specialty fruits, particularly guava. Developing new fruit fly attractants (e.g., host-based kairomones) and alternative plant-based toxicants are promising approaches for improving monitoring tools and pest suppression strategies while minimizing pest management's environmental impact [6,7]. Thus, the evaluation of EOs for novel bioactive compounds is critical to developing alternatives to conventional pest control methods.

Juniper EOs are well documented for their insecticidal and acaricidal activity against a variety of species, including coleopterans (Callosobruchus maculatus, Sitophilus zeamais, S. oryzae, Rhyzopertha dominica, and Tribolium castaneum) [8-11], lepidopterans (Mythimna separata, Plutella xylostella, and Spodoptera exigua) [12,13], a hemipteran (Brevicoryne brassicae) [14], dipterans (Culex pipiens, C. quinquefasciatus, Aedes aegypti and Anopheles stephensi [15-18], and mites (Tetranychus urticae) and Hyalomma aegyptium [19].

Species within the genus Juniperus L. (Cupressaceae) are ever-green trees that play an important role in ecology and economy worldwide [20], and juniper derivatives are widely used in the food, cosmetic and spirits industries [21,22]. Juniperus extracts have been traditionally used in treatment of tuberculosis, jaundice, hemorrhoids, bronchitis, urinary infection, urticaria, rheumatic arthritis, dysentery and the common cold [23-26]. Approximately six percent of the medicinal plants in the world are found in Turkey and the country has an important place in terms of natural wealth. Many of these medicinal and aromatic plants are suitable for essential oil production, including Juniperus foetidissima Willd [27]. The Turkish Ministry of Agriculture and Forestry reported that medicinal and aromatic plants used in food processing, pharmaceuticals, and the cosmetic industry had an export value of 404 million dollars in 2021 [28]. Juniperus is represented by 10 taxa among 7 species, which are mostly distributed in the western, southern, and central parts of Turkey [8]. Juniperus foetidissima, locally known as "Kokulu Ardıç" (fragrant juniper), has the reputation for superior grade furniture and wood products due to its fine odor and resistance to many insect pests [20,29-31].

The current study was conducted to: (i) isolate J. foetidissima EOs from the leaves (JFLEO) and fruits (JFFEO) of populations growing wild in central Turkey, (ii) identify and quantify the chemical contents of JFLEO and JFFEO by gas chromatography-flame ionization detection (GC-FID) and gas chromatography-mass spectrometry (GC-MS), (iii) evaluate these oils for their potential attraction of male C. capitata, and (iv) determine the toxicities of these oils to the female $A$. suspensa.

\section{Results and Discussion}

In the present study, the yields of JFLEO and JFFEO were $2.36 \%$ and $2.98 \%(\mathrm{v} / \mathrm{w})$, respectively. The range of the yield for $J$. foetidissima EOs reported in other published studies is given in Table 1. Our results for JFLEO yield agree with those reported by Adams [32]. However, our yield of JFFEO was higher than that obtained in all other studies. The high percentage yield in our isolations may be attributed to the favorable climate and soil structure of the region selected for the sample collection.

Table 1. Comparison of oil yields of JFLEO and JFFEO reported in the literature.

\begin{tabular}{lll}
\hline Part of $\boldsymbol{J}$. foetidissima & \% & References \\
\hline & 0.30 & {$[33]$} \\
& 1.03 & {$[34]$} \\
& 1.40 & {$[35]$} \\
Leaves (needles) & 2.26 & {$[32]$} \\
& 3.00 & {$[36]$} \\
& 0.68 & {$[37]$} \\
& 0.60 & {$[38]$} \\
& 0.50 & {$[39]$} \\
\hline
\end{tabular}


Table 1. Cont.

\begin{tabular}{lll}
\hline Part of J. foetidissima & \% & References \\
\hline & 0.90 & {$[33]$} \\
& 0.64 & {$[34]$} \\
Fruits & 2.03 & {$[37]$} \\
& 1.70 & {$[41]$} \\
& 2.30 & {$[38]$} \\
& 0.30 & {$[39]$} \\
\hline
\end{tabular}

\subsection{GC-MS Analysis}

The chemical composition of the essential oils from J. foetidissima leaves and fruits is shown in Table 2. In total, 62 compounds were detected. In the fruit, 44 components were identified, while 60 components were identified in the leaves. The main compounds detected in JFLEO were $\alpha$-pinene $(45.2 \%)$ and cedrol $(18.2 \%)$. The major compounds detected in JFFEO were $\alpha$-Pinene (41.9\%), $\alpha$-thujone (12.2\%) and $\beta$-thujone (25.1\%). (Total ion chromatograms are given in the Supplementary Material, Figures S1 and S2).

Table 2. Composition of the essential oils from leaves (JFLEO) and fruit (JFFEO) of Juniperus foetidissima.

\begin{tabular}{|c|c|c|c|c|c|c|c|}
\hline & $\mathrm{Nr}$ & $\mathbf{K I}^{\mathbf{a}}$ & $\mathbf{R R I}^{b}$ & Compound & $\begin{array}{l}\text { JFLEO } \\
\%\end{array}$ & $\begin{array}{l}\text { JFFEO } \\
\%\end{array}$ & IM \\
\hline \multirow{14}{*}{$\begin{array}{l}\text { Monoterpene } \\
\text { hydrocarbons } \\
(\mathrm{MH})\end{array}$} & 1 & $1012^{c}$ & 1014 & Tricyclene & 0.2 & 0.2 & MS \\
\hline & 2 & $1025^{d}$ & 1032 & $\alpha$-pinene & 45.2 & 41.9 & RRI, MS \\
\hline & 3 & $1026^{c}$ & 1035 & $\alpha$-thujene & 0.5 & 0.2 & MS \\
\hline & 4 & $1061^{\mathrm{c}}$ & 1072 & $\alpha$-fenchene & 0.3 & $\operatorname{tr}$ & MS \\
\hline & 5 & $1077^{\mathrm{e}}$ & 1076 & Camphene & 0.4 & 0.1 & RRI, MS \\
\hline & 6 & $1117^{\mathrm{d}}$ & 1118 & $\beta$-pinene & 0.5 & 0.7 & RRI, MS \\
\hline & 7 & $1122^{c}$ & 1132 & Sabinene & 1.1 & 1.2 & MS \\
\hline & 8 & $1122^{c}$ & 1135 & Thuja-2,4(10)-diene & 0.1 & 0.1 & MS \\
\hline & 9 & $1122-1169^{c}$ & 1159 & $\delta$-3-carene & 1.1 & 0.2 & MS \\
\hline & 10 & $1160^{c}$ & 1174 & Myrcene & 0.8 & 0.9 & RRI, MS \\
\hline & 11 & $1248^{c}$ & 1187 & $o$-cymene & 0.1 & $\operatorname{tr}$ & MS \\
\hline & 12 & $1212^{\mathrm{e}}$ & 1203 & Limonene & 3.0 & 1.0 & RRI, MS \\
\hline & 13 & $1188-1233^{c}$ & 1218 & $\beta$-phellandrene & 0.1 & $\operatorname{tr}$ & MS \\
\hline & 14 & $1282^{\mathrm{e}}$ & 1280 & $p$-cymene & 3.6 & 1.7 & RRI, MS \\
\hline \multirow{27}{*}{$\begin{array}{l}\text { Oxygenated } \\
\text { monoterpenes } \\
(\mathrm{OM})\end{array}$} & 15 & $1331-1384^{c}$ & 1384 & $\alpha$-pinene oxide & 0.5 & 1.4 & MS \\
\hline & 16 & $1399^{c}$ & 1406 & $\alpha$-fenchone & $\operatorname{tr}$ & - & RRI, MS \\
\hline & 17 & $1423^{c}$ & 1437 & $\alpha$-thujone & 0.2 & 12.2 & MS \\
\hline & 18 & $1439^{c}$ & 1451 & $\beta$-thujone & 6.7 & 25.1 & MS \\
\hline & 19 & & 1458 & cis-1,2-limonene epoxide & 0.7 & - & MS \\
\hline & 20 & $1459^{\mathrm{e}}$ & 1474 & trans-sabinene hydrate & - & 0.2 & MS \\
\hline & 21 & $1473^{\mathrm{e}}$ & 1481 & Fencyl acetate & 0.1 & - & MS \\
\hline & 22 & $1486^{\mathrm{f}}$ & 1499 & $\alpha$-campholene aldehyde & 0.1 & 0.1 & MS \\
\hline & 23 & $1515^{c}$ & 1532 & Camphor & $\operatorname{tr}$ & $\operatorname{tr}$ & RRI, MS \\
\hline & 24 & $1543^{c}$ & 1553 & Linalool & 0.1 & - & RRI, MS \\
\hline & 25 & & 1556 & cis-sabinene hydrate & - & 0.1 & MS \\
\hline & 26 & $1584^{c}$ & 1571 & trans-p-Menth-2-en-1-ol & 0.1 & 0.1 & MS \\
\hline & 27 & $1575^{c}$ & 1586 & Pinocarvone & - & 0.1 & RRI, MS \\
\hline & 28 & $1568^{\mathrm{f}}$ & 1591 & Fenchyl alcohol & 0.7 & - & RRI, MS \\
\hline & 29 & $1579^{c}$ & 1591 & Bornyl acetate & 1.2 & 0.5 & RRI, MS \\
\hline & 30 & $1601^{c}$ & 1611 & Terpinen-4-ol & 3.1 & 2.7 & RRI, MS \\
\hline & 31 & $1614^{c}$ & 1638 & cis- $p$-menth-2-en-1-ol & 0.2 & 0.1 & MS \\
\hline & 32 & $1631^{c}$ & 1648 & Myrtenal & 0.3 & 0.3 & MS \\
\hline & 33 & & 1658 & Sabinyl acetate & 0.8 & 0.9 & MS \\
\hline & 34 & $1661^{\mathrm{c}}$ & 1670 & trans-pinocarveol & 0.3 & 0.3 & RRI, MS \\
\hline & 35 & $1680^{c}$ & 1683 & trans-verbenol & 0.9 & 0.9 & RRI, MS \\
\hline & 36 & $1694^{c}$ & 1706 & $\alpha$-terpineol & 0.7 & 0.3 & RRI, MS \\
\hline & 37 & $1699^{c}$ & 1719 & Borneol & 0.2 & 0.1 & RRI, MS \\
\hline & 38 & $1720^{c}$ & 1725 & Verbenone & 0.4 & 0.4 & RRI, MS \\
\hline & 39 & $1743-1808^{c}$ & 1804 & Myrtenol & 0.2 & 0.2 & MS \\
\hline & 40 & $1836^{c}$ & 1845 & trans-carveol & 0.3 & 0.1 & RRI, MS \\
\hline & 41 & $1813-1865^{c}$ & 1864 & p-Cymen-8-ol & 0.3 & 0.2 & RRI, MS \\
\hline
\end{tabular}


Table 2. Cont.

\begin{tabular}{|c|c|c|c|c|c|c|c|}
\hline & $\mathrm{Nr}$ & $\mathrm{KI}^{\mathrm{a}}$ & $\mathbf{R R I}^{\mathrm{b}}$ & Compound & $\begin{array}{l}\text { JFLEO } \\
\%\end{array}$ & $\begin{array}{l}\text { JFFEO } \\
\%\end{array}$ & IM \\
\hline \multirow{9}{*}{$\begin{array}{l}\text { Sesquiterpene } \\
\text { hydrocarbons } \\
\text { (SH) }\end{array}$} & 42 & & 1519 & $\begin{array}{l}\text { 1,7-diepi- } \alpha \text {-cedrene } \\
(=\alpha \text {-funebrene) }\end{array}$ & 0.1 & $\operatorname{tr}$ & MS \\
\hline & 43 & $1563-1608^{c}$ & 1577 & $\alpha$-cedrene & 0.6 & - & MS \\
\hline & 44 & & 1594 & $\begin{array}{l}\text { 1,7-diepi- } \beta \text {-cedrene } \\
(=\beta \text {-funebrene })\end{array}$ & 0.9 & $\operatorname{tr}$ & MS \\
\hline & 45 & $1574-1647^{c}$ & 1613 & $\beta$-cedrene & 0.5 & - & MS \\
\hline & 46 & $1597-1648^{c}$ & 1644 & Widdrene (=Thujopsene) & 0.2 & - & MS \\
\hline & 47 & $1649^{c}$ & 1661 & Alloaromadendrene & 0.4 & - & MS \\
\hline & 48 & & 1747 & $\alpha$-alaskene & 0.2 & - & MS \\
\hline & 49 & $1766-1849^{c}$ & 1849 & Cuparene & 0.2 & $\operatorname{tr}$ & MS \\
\hline & 50 & $2146-2256^{c}$ & 2256 & Cadalene & 0.1 & - & MS \\
\hline \multirow{7}{*}{$\begin{array}{l}\text { Oxygenated } \\
\text { sesquiterpenes } \\
\text { (OS) }\end{array}$} & 51 & $2088^{c}$ & 2088 & 1-epi-cubenol & 0.2 & - & MS \\
\hline & 52 & & 2100 & allo-cedrol & 1.0 & 0.2 & MS \\
\hline & 53 & $2093-2149^{c}$ & 2143 & cedrol & 18.2 & 2.1 & RRI, MS \\
\hline & 54 & & 2170 & epi-cedrol & 0.2 & - & MS \\
\hline & 55 & $2165^{\mathrm{e}}$ & 2187 & $\tau$-cadinol & 0.1 & - & MS \\
\hline & 56 & $2135-2219^{c}$ & 2219 & $\delta$-cadinol $(=\alpha$-muurolol) & 0.1 & - & MS \\
\hline & 57 & & 2255 & $\alpha$-cadinol & 0.2 & - & MS \\
\hline \multirow{6}{*}{ Others } & 58 & $1056-1106^{c}$ & 1093 & Hexanal & $\operatorname{tr}$ & 0.2 & RRI, MS \\
\hline & 59 & & 1379 & $\begin{array}{l}\text { 3-methyl-3-butenyl } \\
\text { isovalerate }\end{array}$ & 0.1 & - & MS \\
\hline & 60 & & 1452 & $\alpha, p$-dimethylstyrene & 0.1 & $\operatorname{tr}$ & MS \\
\hline & 61 & & 1617 & Hexyl hexanoate & 0.1 & - & RRI, MS \\
\hline & 62 & & 1797 & $p$-methyl acetophenone & $\operatorname{tr}$ & $\operatorname{tr}$ & MS \\
\hline & & & & Total & 98.6 & 97.0 & \\
\hline
\end{tabular}

${ }^{\mathrm{a}}$ KI from the literature; ${ }^{\mathrm{c}, \mathrm{d}, \mathrm{e}, \mathrm{f}}$ [42-45]; ${ }^{\mathrm{b}}$ RRI-relative retention indices calculated against $n$-alkanes, $\%$ calculated from FID data; tr- trace $(<0.1 \%)$; IM-the identification method based on the relative retention indices (RRI) of authentic compounds on the HP Innowax column and by matching mass spectra (MS) with those of the Wiley and MassFinder libraries and comparisons with literature data.

Quantitatively, the predominant components of juniper essential oils consisted of monoterpene hydrocarbons (MH; JFLEO, 57\%; JFFEO, 48.2\%) and oxygenated monoterpenes (OM; JFLEO, 18.1\%; JFFEO, 46.3\%). Oxygenated sesquiterpenes were higher in leaves as compared to the fruit (OS; JFLEO, 20\%; JFFEO, 2.3\%) and sesquiterpene hydrocarbons were low in leaves and detected only in trace amounts in the fruit (SH; JFLEO, 3\%; JFFEO, $0 \%$ ) (Figure 1; Table 2).

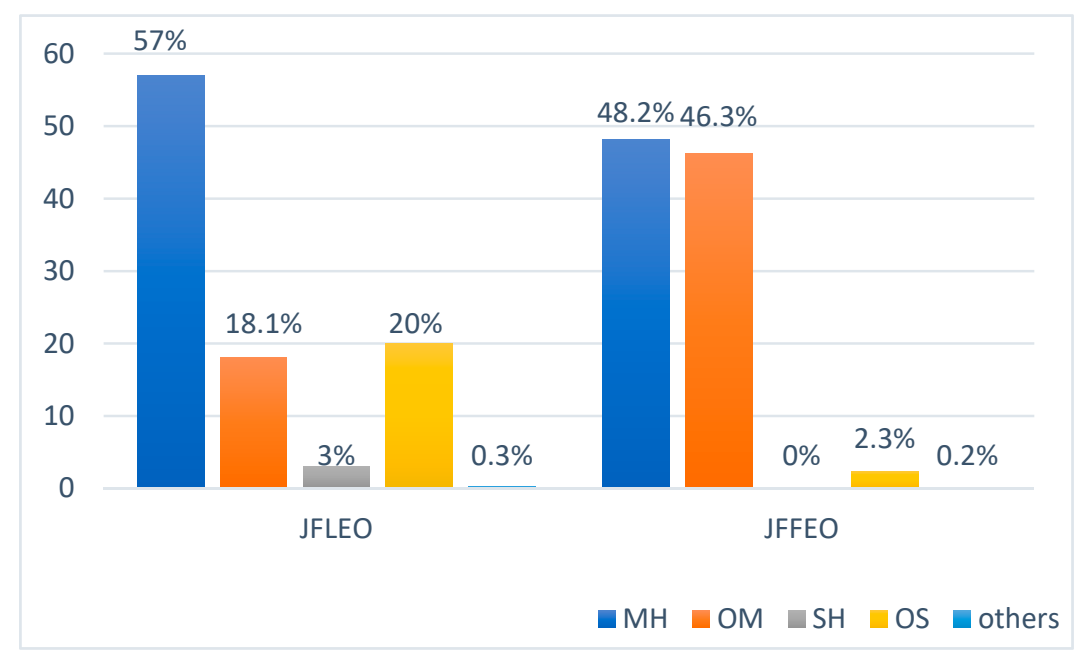

Figure 1. Percent composition of terpene groups in the EOs from the leaves and fruit of J. foetidissima. $\mathrm{MH}$-monoterpene hydrocarbons; OM-oxygenated monoterpenes; $\mathrm{SH}$-sesquiterpene hydrocarbons; OS-oxygenated sesquiterpenes.

Although J. foetidissima EOs have been investigated in different countries and regions of the same country, they continue to be of interest for both industrial and research pur- 
poses. Table 3 summarizes data from literature reports on the main components identified in J. foetidissima EOs obtained from the leaves, fruit, branches, and wood [33,34,36,37,46-50]. The chemical composition of JFFEO from the Arasbaran forest in Iran showed significant quantitative and qualitative differences [36,41,47]; sabinene, $\alpha$-pinene, and limonene were the main components, but all three were present in different percentages. In contrast, limonene, $\alpha$-thujone, $\beta$-thujone and terpinen- 4 -ol were determined to be the main components in the study of Parvin Salehi et al. [41]. In the study of Lesjak et al. [21] in Macedonia, sabinene and terpinen-4-ol in the leaf oil and only sabinene in the fruit oil were found to be the main components. In another study on JFFEO, Adam collected fruit samples from Greece and reported sabinene, $\alpha$-thujone, and terpinen-4-ol to be the main components [46], whereas samples collected at three locations in Turkey had significantly different components. In samples collected from Amasya, a city in northern Turkey, it was reported that the main components of JFLEO were $\alpha$-pinene and cedrol and the main component of JFLEO was $\alpha$-pinene [34].

Table 3. Predominant components of EOs isolated from different parts of J. foetidissima, as reported in the literature $[33,34,36,37,46-50]$.

\begin{tabular}{|c|c|c|c|}
\hline Part of J. foetidissima & Main Components & $\%$ & References \\
\hline \multirow{12}{*}{ Leaves (needles) } & \multirow{3}{*}{ sabinene } & 39.9 & [37] \\
\hline & & 15.9 & [46] \\
\hline & & 19.9 & [36] \\
\hline & \multirow{2}{*}{ cedrol } & 11.4 & [33] \\
\hline & & 25.5 & [34] \\
\hline & \multirow{2}{*}{$\alpha$-pinene } & 56.1 & [34] \\
\hline & & 22.2 & [36] \\
\hline & $\alpha$-thujone & 18.6 & [46] \\
\hline & $\beta$-thujone & 26.5 & [33] \\
\hline & \multirow{2}{*}{ terpinen-4-ol } & 17.0 & [37] \\
\hline & & 17.6 & [46] \\
\hline & limonene & 20.9 & [36] \\
\hline \multirow{14}{*}{ Fruit } & \multirow{4}{*}{ sabinene } & 23.7 & [33] \\
\hline & & 29.9 & [37] \\
\hline & & 27.1 & [47] \\
\hline & & 37.1 & {$[36]$} \\
\hline & \multirow{3}{*}{$\alpha$-pinene } & 90.2 & [34] \\
\hline & & 19.8 & [47] \\
\hline & & 29.9 & [36] \\
\hline & \multirow{4}{*}{ limonene } & 13.1 & [33] \\
\hline & & 25.5 & [47] \\
\hline & & 11.8 & [36] \\
\hline & & 22.29 & [41] \\
\hline & $\alpha$-thujone & 13.46 & [41] \\
\hline & $\beta$-thujone & 22.32 & [41] \\
\hline & terpinen-4-ol & 15.4 & [41] \\
\hline \multirow{5}{*}{ Branches } & \multirow{2}{*}{ sabinene } & 19.1 (male) & \multirow{5}{*}{ [47] } \\
\hline & & 34.3 (female) & \\
\hline & $\alpha$-pinene & 17.4 (male) & \\
\hline & -p-pmene & 8.7 (female) & \\
\hline & limonene & 36.3 (male) & \\
\hline
\end{tabular}


Table 3. Cont.

\begin{tabular}{|c|c|c|c|}
\hline Part of J. foetidissima & Main Components & $\%$ & References \\
\hline \multirow{4}{*}{ Wood } & thujopsene & $\begin{array}{l}19.82 \text { (sapwood) } \\
23.78 \text { (heartwood) }\end{array}$ & \multirow{4}{*}{ [48] } \\
\hline & widdrol & $\begin{array}{l}3.0 \text { (sapwood) } \\
15.83 \text { (heartwood) }\end{array}$ & \\
\hline & cedrol & $\begin{array}{l}18.8 \text { (sapwood) } \\
10.0 \text { (heartwood) }\end{array}$ & \\
\hline & caryophyllene alcohol & $\begin{array}{l}25.0 \text { (sapwood) } \\
8.9 \text { (heartwood) }\end{array}$ & \\
\hline
\end{tabular}

Samples from Eskisehir Province (central Anatolia, Turkey) studied showed that cedrol and $\beta$-thujone were the main components in JFLEO, and that sabinene and limonene were the main components in JFFEO [33]. Another study of samples from Antalya Province, Turkey showed that thujopsene, widdrol, cedrol, and caryophyllene alcohol were the main components in sapwood and heartwood oils [48].

In the present study, the main components were determined to be $\alpha$-pinene and cedrol in JFLEO and $\alpha$-pinene, $\alpha$-thujone, and $\beta$-thujone in JFFEO; these results agree with those reported by Yaglioglu et al. [34]. Moreover, it is noteworthy that $\alpha$-pinene is the main component in only Turkish and Iranian essential oils. The studies by Tunalier et al. [33] and Yaglioglu et al. [34] were also similar regarding the relatively high content of cedrol. As a general result of these studies, it can be concluded that the chemical composition of volatile compounds in JFEOs may be highly variable, depending on the age of the tree, location, geographic variations, and climatic and ecological conditions of the area in which the tree is located. Considering all these influences, the oil's composition is highly dependent on these factors. As a result, the JFLEO and JFFEO profiles and the EO yields were quite different and may be of interest to the EO industry utilizing juniper leaf and fruit EOs.

\subsection{Biological Activity of Juniperus foetidissima Essential Oils}

\subsubsection{Attraction of the Mediterranean Fruit Fly}

In short-range attraction bioassays of male $C$. capitata, there were significant differences in their behavioral response to the six essential oil treatments $(F=7.107 ; \mathrm{df}=5.24 ; p<0.001$; Figure 2). Both JFLEO and JFFEO were found to be highly attractive to males, with results comparable to those observed in the two positive controls, tea tree essential oil (TTO) [49] and Tetradenia riparia essential oil (TREO) [50]. Their attraction to the best three oils-JFFEO, TTO, and TREO—-was significantly greater than that observed with blue tansy essential oil (BTEO) [51] or mastic gum essential oil (MGEO) [52].

Comparing the two JFEOs, the higher response to JFFEO suggests that the activity may be related to the thujone concentration. JFFEO contains a higher percentage of both $\alpha$ - and $\beta$ thujone (12.2\% and $25.1 \%$, respectively), which accounted for $37 \%$ of the total composition (Table 2). The isomers $\alpha$ - and $\beta$-thujone are monoterpene ketones and naturally occur in the essential oils of Thuja occidentalis, Tanacetum vulgare, Salvia officinalis, and Artemisia absinthium [53]. Previous studies highlighted that the thujone accumulation reaches higher levels in the leaf and budding floral stages and changes after the flowering and during the seed ripening in S. officinalis and A. absinthium EOs [53]. In the case of T. vulgare, $\beta$-thujone in the flower was higher than it was in the leaf oil in a Dutch tansy oil [54]. However, literature data reveals that the thujone content can vary depending on the plant species, harvested time, and region or habitat from which the sample originates [53]. Comparing previously reported Juniperus EOs, thujones were detected in relatively low concentrations or were lacking in nine Juniperus EOs (J. chinensis, J. communis, J. excelsa, J. macropoda, J. phoenicea, J. saltuaria, J. scopulorum, J. squamata, and J. virginiana), whereas thujones were found in higher amounts in J. foetidissima EOs [31,33,53,55-58]. 


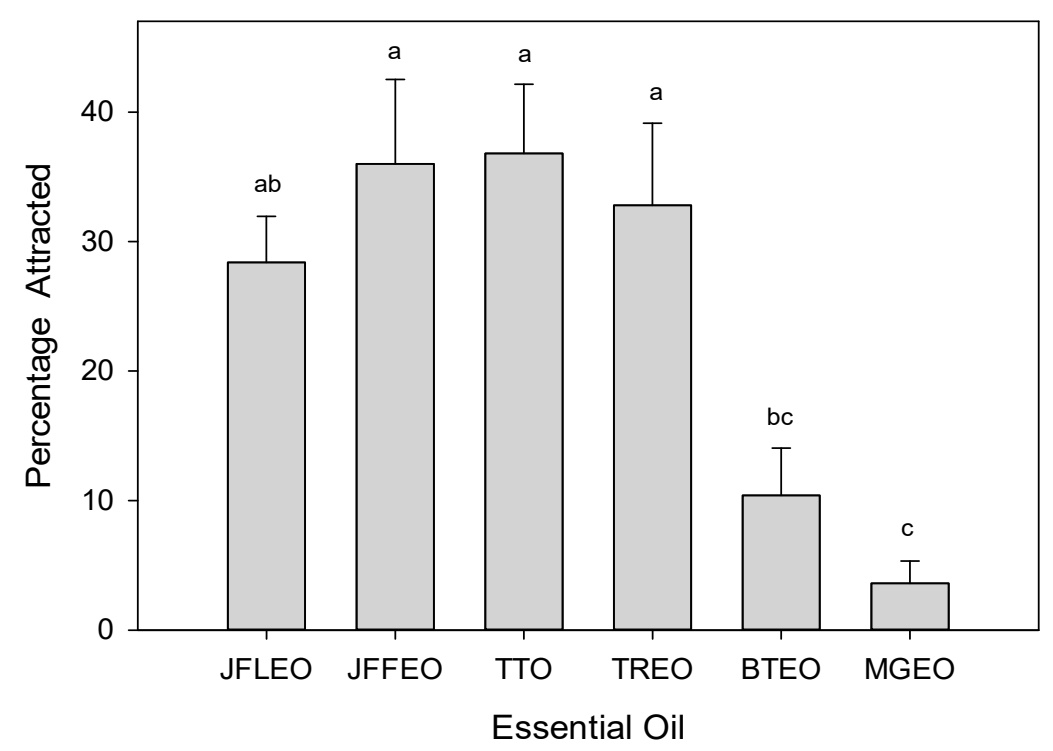

Figure 2. Juniperus foetidissima leaf essential oil (JFLEO) and fruit essential oil (JFFEO) vs. controls: two strong attractants (TTO, TREO) and two mild attractants (BTEO, MGEO). Bars topped with the same letter are not significantly different (Tukey's HSD mean separation; $p<0.05$ ).

Numerous studies reported that thujones exhibit various types of bioactivity, such as antifeedant activity against Sitka black-tailed deer (Odocoileus hemionus sitkensis) [59], toxicity to the larvae and adults of the sycamore lace bug (Corythucha ciliata) [60], high toxicity to western corn rootworm larvae (Diabrotica virgifera virgifera), and less toxicity to the two-spotted spider mite (Tetranychus urticae) and housefly (Musca domestica) [61]. In choice and no-choice tests with the peach-potato aphid (Myzus persicae), as well as in electropenetrography (EPG) analyses, $\beta$-thujone caused changes in the aphid's feeding behavior, while $\alpha$-thujene did not evoke any changes [62]. The authors conducted further studies on $\beta$-thujone derivatives, and found that $\beta$-thujone and four $\beta$-thujone derivatives showed an antifeedant activity against $M$. persicae, which might be used for selective integrated pest management (IPM) control strategies against peach-potato aphids.

Our present results identify JFFEO as an effective new attractant to male $C$. capitata with the potential to improve field lures for this pest. The major constituents detected in JFFEO were $\alpha$-pinene ( $41.9 \%), \beta$-thujone (25.1\%), and $\alpha$-thujone (12.2\%). These compounds are different than those identified previously in other EOs highly attractive to the medfly. The predominant components in TTO include terpinen-4-ol (41.8\%), $\gamma$-terpinene (15.5\%), and $p$-cymene (11.9\%) [49]. The primary components in TREO consist of fenchone (15\%), $\delta$-cadinene (11\%), 14 -hydroxy- $\beta$-caryophyllene $(8 \%)$, and $\tau$-cadinol $(7 \%)$ [50]. In addition, early work on Angelica seed oil identified $\alpha$-copaene as a strong attractant to male $C$. capitata [63]. Further studies are needed to determine whether combinations of two or more of these EOs result in an increase in their attraction of medflies. For other pest insects, improved lures have been developed through a combination of multiple kairomones that work synergistically [64].

\subsubsection{Toxicity to the Caribbean Fruit Fly}

The present study demonstrated that J. foetidissima EOs had strong toxicity to adult female $A$. suspensa. The median lethal doses $\left(\mathrm{LD}_{50}\right)$ of JFLEO and JFFEO for $A$. suspensa were $22.07\left(\chi^{2}=7.232, \mathrm{df}=4, p=0.1241\right)$ and $10.45 \mu \mathrm{g} / \mu \mathrm{L}\left(\chi^{2}=6.6917, \mathrm{df}=4, p=0.1531\right)$, respectively (Table 4). Our results also showed that an untreated control had a $0 \%$ adult mortality during the test, and a topical application with acetone alone resulted in a $6.7 \%$ adult mortality. A dose of $10.46 \mu \mathrm{g} / \mu \mathrm{L}$ of JFFEO was required to achieve a $50 \%$ mortality of A. suspensa, which was less than half the dose of JFLEO required, $22.07 \mu \mathrm{g} / \mu \mathrm{L}$. This could be due to the different chemical compositions of the two essential oils. The primary component of both J. foetidissima EOs is $\alpha$-pinene, which has demonstrated insecticidal 
effects on several insect pests including the medically important head louse, Pediculus humanus, and a stored product pest, the maize weevil, Sitophilus zeamais $[65,66]$. In S. zeamais, $\alpha$-pinene also demonstrated a reduction in their progeny of up to $98 \%$ at a dose of $12 \mathrm{ppm}$ via contact. In addition, monoterpenes such as $\alpha$-pinene are typically volatile chemicals with a demonstrated fumigation toxicity to some insect pests, including S. zeamais. [66]. Our results showed that JFFEO had a stronger toxicity to A. suspensa female adults than JFLEO. This could be due to other chemicals in the composition (e.g., $\alpha$-thujone and $\beta$-thujone) of JFFEO that may contribute to synergistic insecticidal effects on $A$. suspensa. For example, $(\alpha+\beta)$ thujone showed toxicity to the red imported fire ant (Solenopsis invicta) when used as a fumigant and achieved a $100 \%$ mortality with an appropriate dose-dependent treatment [67]. It is speculated that a synergistic effect between $\alpha$-pinene and $(\alpha+\beta)$ thujone may have played an important role in improving the toxicity. However, further studies are needed to verify the synergistic effect. Our results demonstrated a strong contact toxicity of the two EOs to A. suspensa; they may also have the potential to work as fumigants in insect pest control due to their volatile attributes. Therefore, J. foetidissima EOs may improve fruit fly pest control programs through a combination of both contact and fumigation treatments, but further studies are needed to justify the feasibility.

Table 4. Median lethal dose $\left(\mathrm{LD}_{50}\right)$ of J. foetidissima $\mathrm{EO}$ for the control of the adult female Caribbean fruit fly, A. suspensa, under laboratory conditions.

\begin{tabular}{lllllll}
\hline J.foetidissima EO & $\boldsymbol{n}$ & Slope $( \pm$ SE) & LD $_{\mathbf{5 0}}(\mathbf{9 5} \%$ FL) & $\chi^{2}$ & df & $p$ \\
\hline JFLEO & 240 & $1.34 \pm 0.12$ & $22.07(17.56-29.34)$ & 7.2320 & 4 & 0.1241 \\
JFFEO & 240 & $2.10 \pm 0.15$ & $10.45(9.13-12.08)$ & 6.6917 & 4 & 0.1531 \\
\hline
\end{tabular}

A probit analysis was used to calculate the $\mathrm{LD}_{50}$ lethal dose of J. foetidissima oils in adult females of $A$. suspensa (PROC PROBIT, SAS Institute Inc.: Cary, NC, USA, 2020).

\section{Materials and Methods}

\subsection{Plant Material}

Leaves and fruits of J. foetidissima were collected from Beypazari town in Ankara Province, Turkey (Figures S3 and S4). The specimens were authenticated by Dr. Barbaros Yaman and have been deposited in the Herbarium of the Faculty of Forestry, Bartin University (BOF 516). Fresh and undamaged samples were collected and stored at $-24{ }^{\circ} \mathrm{C}$ until the laboratory analyses.

\subsection{Essential Oil Isolation}

Essential oils of the leaf and fruit of J. foetidissima were obtained by hydrodistillation using a Clevenger apparatus (Ildam Cam Ltd., Ankara, Turkey). One hundred grams each of fresh leaves and fruits were used, and the oils were collected for $3 \mathrm{~h}[68,69]$. The samples were dried with anhydrous sodium sulphate in a sealed vial until analyses [70].

\subsection{GC-MS Analysis}

The GC-MS analysis was carried out with an Agilent 5975 GC-MSD system (Agilent Technologies, Santa Clara, CA, USA). An Innowax FSC column $(60 \mathrm{~m} \times 0.25 \mathrm{~mm}, 0.25 \mu \mathrm{m}$ film thickness) was used with helium as the carrier gas $(0.8 \mathrm{~mL} / \mathrm{min})$. GC oven temperature was kept at $60^{\circ} \mathrm{C}$ for $10 \mathrm{~min}$, programmed to $220^{\circ} \mathrm{C}$ at a rate of $4{ }^{\circ} \mathrm{C} / \mathrm{min}$ and kept constant at $220^{\circ} \mathrm{C}$ for $10 \mathrm{~min}$, and then programmed to $240{ }^{\circ} \mathrm{C}$ at a rate of $1{ }^{\circ} \mathrm{C} / \mathrm{min}$. The split ratio was set at $40: 1$. The injector temperature was set at $250^{\circ} \mathrm{C}$. Mass spectra were recorded at $70 \mathrm{eV}$. Mass range was from $\mathrm{m} / \mathrm{z} 35$ to 450 .

\subsection{GC Analysis}

The GC analysis was carried out using an Agilent 6890N GC system (Agilent Technologies, Santa Clara, CA, USA). FID detector temperature was $300^{\circ} \mathrm{C}$. To obtain the same elution order as with GC-MS, simultaneous auto-injection was done on a duplicate of the 
same column applying the same operational conditions. Relative percentage amounts of the separated compounds were calculated from FID chromatograms. The analysis results are given in Table 2.

\subsection{Identification of the Compounds}

Compounds were identified by comparison of the chromatographic peaks retention times with those of standards analyzed under the same conditions, and by comparison of the retention indices (RI), as Kovats indices, [71] as well as MS literature data [72,73]. Comparisons of MS fragmentation patterns with those of standards and mass spectrum database search were performed using the commercial Wiley GC-MS Library, MassFinder Software 4.0 [74] and the in-house "Baser Library of Essential Oil Constituents" built up by genuine compounds and components of known oils.

\subsection{Laboratory Bioassays}

\subsubsection{Short-Range Attraction Bioassays with Ceratitis capitata}

Sterile male C. capitata were used in all bioassays. The source of insects, laboratory rearing procedures, and short-range attraction bioassays were identical to those described previously [49]. All tests were conducted at room temperature in screened cages $(20.3 \times 20.3 \times 20.3 \mathrm{~cm})$ into which 50 flies were introduced $1 \mathrm{~h}$ prior to initiation of an experiment. Assays were started by introducing a Petri dish (53 mm diameter $\times 12 \mathrm{~mm}$ height) containing a filter paper disk (Whatman \#1, $3.5 \mathrm{~cm}$ diameter) soaked with the test EO (10 $\mu \mathrm{L}$ of a $10 \%$ dilution in acetone). Separate cages were used for each test to observe medfly response to: (1) JFLEO, Juniperus foetidissima leaf essential oil; (2) JFFEO, J. foetidissima fruit essential oil; (3) TTO, tea tree oil, a known strong attractant [49] derived from Melaleuca alternifolia (Maiden and Betche) Cheel (Essential Oil India-SAT Group, Kannauj, India); (4) TREO, Tetradenia riparia essential oil, a known strong attractant obtained from Tetradenia riparia (Hochst.) Codd as described in Blythe et al. [50]; (5) BTEO, blue tansy essential oil, a mild attractant obtained from Tanacetum anuum L. as described in Stappen et al. [51]; and (6) MGEO, mastic gum essential oil, a mild attractant obtained from Pistacia lentiscus L. var. chia as described in Tabanca et al. [52]. After $30 \mathrm{~min}$, response was recorded as the number of flies within a Petri dish, which was subsequently converted to the percentage of flies attracted. All tests were replicated five times, and the position of the cages was randomized between replicate runs.

\subsubsection{Toxicity of JFEOs to Anastrepha suspensa}

Topical bioassays using thoracic application to adult female Anastrepha suspensa were conducted to determine the toxicities of JFLEO or JFFEO under laboratory conditions at $26 \pm 1{ }^{\circ} \mathrm{C}, 70 \pm 5 \% \mathrm{RH}$, and 12:12 L:D photoperiod. To prepare the stock solution, $100 \mu \mathrm{g}$ of JFLEO or JFFEO was diluted in $1 \mu \mathrm{L}$ of dimethyl sulfoxide (DMSO) to establish a $100 \mu \mathrm{g} / \mu \mathrm{L}$ solution. To evaluate the toxicities of the two EOs, a serial dilution of stock solution was prepared with acetone to establish $1.25,2.5,5,10,15$, and $50 \mu \mathrm{g} / \mu \mathrm{L}$ solutions, and each dilution was tested in topical bioassays.

To conduct topical bioassays, pupae of $A$. suspensa were collected in a tray and placed inside a screen cage $(30 \mathrm{~cm} \times 30 \mathrm{~cm} \times 30 \mathrm{~cm})$ under the laboratory conditions described above to allow for adult emergence. Newly emerged female adults ( $<3 \mathrm{~d}$ old) were collected using an aspirator into a plastic vial $(3 \mathrm{~cm}$ in diameter $\times 8 \mathrm{~cm}$ in height). Female adults in the vial were first chilled at $4{ }^{\circ} \mathrm{C}$ in a refrigerator for $5 \mathrm{~min}$ to calm the flies, and calmed flies were then removed from the refrigerator to a petri dish to facilitate the topical application. A repeating dispenser equipped with gastight and microliter syringe $(50 \mu \mathrm{L})(\mathrm{PB} 600$, Hamilton Company, Reno, NV, USA) was used to apply $1 \mu \mathrm{L}$ dilution at each concentration of each EO on the dorsal thorax of the calmed adult flies. After topical application, the adult flies were immediately transferred into a plastic cup $(6 \mathrm{~cm}$ in diameter $\times 7.4 \mathrm{~cm}$ in height $)$ and covered with a mesh screen for post-treatment observation. After $24 \mathrm{~h}$, numbers of live and dead flies were documented and mortality of A. suspensa in each treatment was 
calculated. Untreated female adults and those treated with acetone alone were used as controls. For each dilution, 10 female adult flies were treated, and each treatment was replicated 3 times. In total, 240 female flies were used in the evaluation of each EO.

\section{Statistical Analysis}

For the attraction bioassays with C. capitata, an analysis of variance (ANOVA) followed by a mean separation with Tukey's HSD test $(p<0.05)$ was used to analyze results (SigmaPlot version 14, Systat Software, Inc.: San Jose, CA, USA) [75].

Mortality data of $A$. suspensa in toxicity bioassays were used to calculate the median lethal dose $\left(\mathrm{LD}_{50}\right)$ for each $\mathrm{EO}$ (JFLEO or JFFEO). Mortality data for each treatment were corrected by mortalities in the untreated control using Abbott's formula [76] prior to the analysis. A probit analysis was then used to calculate the lethal dose corresponding to a $50 \%$ reduction $\left(\mathrm{LD}_{50}\right)$ in the $A$. suspensa's survival based on the regression curve. The statistical analysis was performed using SAS version 9.4 [77].

\section{Conclusions}

In this study, the chemical composition of essential oils from the J. foetidissima leaf (JFLEO) and fruit (JFFEO) were investigated. Our study is the first report to evaluate the attractancy and toxicity of J. foetidissima oils to C. capitata and A. suspensa. The major compounds identified in JFLEO were $\alpha$-pinene and cedrol, while JFFEO contained $\alpha$-pinene, $\alpha$-thujone, and $\beta$-thujone. The differences in chemical composition between the two EOs may account for the differences in their attractiveness and toxicity observed in two tephritid species. JFFEO was found to be more effective than JFLEO in attracting male C. capitata, which might be attributed to the $\alpha$ - and $\beta$-thujone content of JFFEO. Furthermore, JFFEO also showed a much higher toxicity to female $A$. suspensa than JFLEO. Future studies are needed to separate the diastereomers of thujone and evaluate their chemical activities on tephritid species. Further evaluation of plant EOs as novel attractants and toxicants is highly desirable, as they are biodegradable and therefore environmentally friendly. This current report concludes that JFLEO and JFFEO show promise for integration into management programs for major fruit fly pests.

Supplementary Materials: Supplementary materials are available online. Figure S1. Total ion chromatogram of JFLEO; Figure S2. Total ion chromatogram of JFFEO; Figure S3. Juniper (Juniperus foetidissima Willd.) tree (Ankara (Beypazari), Turkey); Figure S4. Fruits and leaves of J. foetidissima (Ankara (Beypazari), Turkey).

Author Contributions: Conceptualization, M.K., I.T., H.K., N.T., X.Y., B.D., and P.E.K.; formal analysis, N.T., X.Y., B.D., and P.E.K.; funding acquisition, P.E.K.; investigation, I.T., N.T., and P.E.K.; methodology, I.T., N.T., X.Y., B.D., and P.E.K.; writing-original draft, M.K., I.T., H.K., N.T., X.Y., B.D., and P.E.K.; writing—review and editing, M.K., I.T., H.K., N.T., X.Y., B.D., and P.E.K.; project administration, P.E.K.; funding acquisition, P.E.K. All authors have read and agreed to the published version of the manuscript.

Funding: This study was supported by appropriated funds from the United States Department of Agriculture, Agricultural Research Service (project number: 6038-22000-007-00-D).

Institutional Review Board Statement: Not applicable.

Informed Consent Statement: Not applicable.

Data Availability Statement: Data is contained within the article.

Acknowledgments: The authors are grateful to Micah Gill, Monica Blanco, Wayne Montgomery, and Elena Schnell (USDA-ARS, SHRS, Miami, FL, USA) for bioassays and laboratory experiments. We also acknowledge Huseyin Sivrikaya (Department of Forest Industrial Engineering, Bartin University, Bartin, Turkey) and Aime Vazquez (USDA-ARS, SHRS, Miami, FL, USA) for providing critical reviews of an earlier version of this manuscript. We also thank journal editors and reviewers for helpful suggestions. 
Conflicts of Interest: The authors declare no conflict of interest. The mention of trade names or commercial products in this publication is solely for the purpose of providing specific information and does not imply recommendation or endorsement by the U.S. Department of Agriculture. USDA is an equal opportunity provider and employer.

Sample Availability: JFLEO and JFFEO are available from M.K. and I.T.

\section{References}

1. Isman, M.B. Plant essential oils for pest and disease management. In Crop Protection; Elsevier: Amsterdam, The Netherlands, 2000; Volume 19, pp. 603-608.

2. Kumar, P.; Mishra, S.; Malik, A.; Satya, S. Repellent, larvicidal and pupicidal properties of essential oils and their formulations against the housefly, Musca domestica. Med. Vet. Entomol. 2011, 25, 302-310. [CrossRef]

3. Tabanca, N.; Bernier, U.R.; Tsikolia, M.; Becnel, J.J.; Sampson, B.; Werle, C.; Demirci, B.; Baser, K.H.C.; Blythe, E.K.; Pounders, C.; et al. Eupatorium capillifolium essential oil: Chemical composition, antifungal activity, and insecticidal activity. Nat. Prod. Commun. 2010, 5, 1409-1415. [CrossRef]

4. Mann, R.S.; Kaufman, P.E. Natural product pesticides: Their development, delivery and use against insect vectors. Mini-Rev. Org. Chem. 2012, 9, 185-202. [CrossRef]

5. Tripathi, A.K.; Upadhyay, S.; Bhuiyan, M.; Bhattacharya, P.R. A review on prospects of essential oils as biopesticide in insect-pest management. J. Pharmacogn. Phyther. 2009, 1, 52-63. [CrossRef]

6. Quilici, S.; Atiama-Nurbel, T.; Brévault, T. Plant odors as fruit fly attractants. In Trapping and the Detection, Control, and Regulation of Tephritid Fruit Flies; Shelly, T., Epsky, N., Jang, E.B., Reyes-Flores, J., Vargas, R., Eds.; Springer Publishing: Berlin/Heidelberg, Germany, 2014; pp. 119-144.

7. Tan, K.H.; Nishida, R.; Jang, E.B.; Shelly, T.E. Pheromones, male lures and trapping of Tephritid fruit flies. In Trapping and the Detection, Control, and Regulation of Tephritid Fruit Flies; Shelly, T., Epsky, N., Jang, E.B., Reyes-Flores, J., Vargas, R., Eds.; Springer Publishing: Berlin/Heidelberg, Germany, 2014; pp. 15-74.

8. Athanassiou, C.G.; Kavallieratos, N.G.; Evergetis, E.; Katsoula, A.-M.; Haroutounian, S.A. Insecticidal efficacy of silica gel with Juniperus oxycedrus ssp. oxycedrus (Pinales: Cupressaceae) essential oil against Sitophilus oryzae (Coleoptera: Curculionidae) and Tribolium confusum (Coleoptera: Tenebrionidae). J. Econ. Entomol. 2013, 106, 1902-1910. [CrossRef]

9. Khani, A.; Rashid, B.; Mirshekar, A. Chemical composition and insecticidal efficacy of Juniperus polycarpus and Juniperus sabina essential oils against Tribolium confusum (Coleoptera: Tenebrionidae). Int. J. Food Prop. 2017, 20, 1221-1229. [CrossRef]

10. Shafaie, F.; Aramideh, S.; Valizadegan, O.; Safaralizadeh, M.H.; Hosseini-Gharalari, A. Efficacy of herbal essential oils against Cowpea weevil. Orient. J. Chem. 2019, 35, 1174-1181. [CrossRef]

11. Mahmoudvand, M.; Abbasipour, H.; Hosseinpour, M.H.; Rastegar, F.; Basij, M. Using some plant essential oils as natural fumigants against adults of Callosobruchus maculatus (F.) (Coleoptera: Bruchidae). Munis Entomol. Zool. 2011, 6, 150-154.

12. Gao, C.; Zhang, X. Fumigant insecticidal action of the essential oil from the seeds of the savin juniper (Sabina vulgaris Ant.). Nanjing Nongye Daxue Xuebao 1997, 3, 50-53.

13. Murcia-Meseguer, A.; Alves, T.J.S.; Budia, F.; Ortiz, A.; Medina, P. Insecticidal toxicity of thirteen commercial plant essential oils against Spodoptera exigua (Lepidoptera: Noctuidae). Phytoparasitica 2018, 46, 233-245. [CrossRef]

14. Isik, M.; Gorur, G. Aphidicidial activity of seven essential oils against the cabbage aphid; Brevicoryne brassicae L: (Hemiptera: Aphididae). Mun. Ent. Zool. 2009, 4, 424-431.

15. Barnard, D.R. Repellency of essential oils to mosquitoes (Diptera: Culicidae). J. Med. Entomol. 1999, 36, 625-629. [CrossRef] [PubMed]

16. Prajapati, V.; Tripathi, A.K.; Aggarwal, K.K.; Khanuja, S.P.S. Insecticidal, repellent and oviposition-deterrent activity of selected essential oils against Anopheles stephensi, Aedes aegypti and Culex quinquefasciatus. Bioresour. Technol. 2005, 96, 1749-1757. [CrossRef] [PubMed]

17. Giatropoulos, A.; Pitarokili, D.; Papaioannou, F.; Papachristos, D.P.; Koliopoulos, G.; Emmanouel, N.; Tzakou, O.; Michaelakis, A. Essential oil composition, adult repellency and larvicidal activity of eight Cupressaceae species from Greece against Aedes albopictus (Diptera: Culicidae). Parasitol. Res. 2013, 112, 1113-1123. [CrossRef]

18. Trongtokit, Y.; Rongsriyam, Y.; Komalamisra, N.; Apiwathnasorn, C. Comparative repellency of 38 essential oils against mosquito bites. Phyther. Res. 2005, 19, 303-309. [CrossRef]

19. El-Mustapha, L.; Abderrafea, E.; Ayoub, K.; Abdelaziz, A.; El Hassan, E.M. Toxicity of essential oils obtained from Juniperus thurifera var. africana and Mentha suaveolens subsp. timija chemotypes against pre-adult stages of Hyalomma aegyptium tick (Acari: Ixodidae). Nat. Prod. Res. 2019, 6419, 1-6. [CrossRef]

20. Baytop, T. Türkiye'de Bitkiler ile Tedavi (Geçmişte ve Bugün); Ankara Nobel Tip Kitabevleri: Ankara, Turkey, 1984; Volume 3255, ISBN 0021-8561.

21. Lesjak, M.M.; Beara, I.N.; Orčić, D.Z.; Anačkov, G.T.; Balog, K.J.; Francišković, M.M.; Mimica-Dukić, N.M. Juniperus sibirica Burgsdorf. As a novel source of antioxidant and anti-inflammatory agents. Food Chem. 2011, 124, 850-856. [CrossRef]

22. Mrabet, A.; Rejili, M.; Lachiheb, B.; Toivonen, P.; Chaira, N.; Ferchichi, A. Microbiological and chemical characterizations of organic and conventional date pastes (Phoenix dactylifera L.) from Tunisia. Ann. Microbiol. 2008, 58, 453-459. [CrossRef] 
23. Tumen, I.; Suntar, I.; Keles, H.; Küpeli Akkol, E. A Therapeutic Approach for Wound Healing by Using Essential Oils of Cupressus and Juniperus Species Growing in Turkey. Evid. -Based Complement. Altern. Med. 2012, 7, 728281. [CrossRef]

24. Muhammad, I.; Mossa, J.S.; El-Feraly, F.S. Antibacterial diterpenes from the leaves and seeds of Juniperus excelsa M. Bieb. Phyther. Res. 1992, 6, 261-264. [CrossRef]

25. Sezik, E.; Yeşilada, E. Turkish folk medicine containing volatile oils. In Essential Oils; Anadolu University Press: Eskisehir, Turkey, 1999; pp. 98-131.

26. Öztürk, M.; Tümen, I.; Uğur, A.; Aydoğmuş-Öztürk, F.; Topçu, G. Evaluation of fruit extracts of six Turkish Juniperus species for their antioxidant, anticholinesterase and antimicrobial activities. J. Sci. Food Agric. 2011, 91, 867-876. [CrossRef]

27. Baser, K.H.C. Flora of Turkey as a source of essential oils. In Proceedings of the 10th International Symposium on the Chemistry of Natural Compounds (10th SCNC), Tashkent, Uzbekistan, 25-29 November 2013.

28. The Bloomberght Home Page. Available online: https://www.bloomberght.com/tibbi-ve-aromatik-bitki-ihracatimiz-404milyon-dolara-ulasti-2270801 (accessed on 28 November 2021).

29. Davis, P. Flora of Turkey and the East Aegean Islands; Edinburgh University Press: Edinburgh, UK, 1965; Volume 1, ISBN 0852245599.

30. Karamanoğlu, K. Türkiye Btikileri, 1st ed.; Ankara University Faculty of Pharmacy: Ankara, Turkey, 1974; pp. 40-42.

31. Tunalier, Z.; Kirimer, N.; Baser, K.H.C. A potential new source of cedarwood oil: Juniperus foetidissima Willd. J. Essent. Oil Res. 2004, 16, 233-235. [CrossRef]

32. Adams, R.P. Variation in the chemical composition of the leaf oil Juniperus foetidissima Willd. J. Essent. Oil Res. 1990, 2, 67-70. [CrossRef]

33. Tunalier, Z.; Kirimer, N.; Baser, K.H.C. The composition of essential oils from various parts of Juniperus foetidissima. Chem. Nat. Compd. 2002, 38, 43-47. [CrossRef]

34. Yaglioglu, A.S.; Eser, F.; Yaglioglu, M.S.; Demirtas, I. The antiproliferative and antioxidant activities of the essential oils of Juniperus species from Turkey. Flavour Fragr. J. 2020, 35, 1-13. [CrossRef]

35. Tayoub, G.; Alorfi, M.; Ismall, H. Fumigate efficacy of Juniperus foetidissima essential oil and two terpenes against Phthorimaea operculella. Herba Polonica 2019, 65, 501-508. [CrossRef]

36. Asili, J.; Emami, S.A.; Rahimizadeh, M.; Fazly-Bazzaz, B.S.; Hassanzadeh, M.K. Chemical and antimicrobial studies of Juniperus sabina L. and Juniperus foetidissima Willd. essential oils. J. Essent. Oil-Bear. Plants 2010, 13, 25-36. [CrossRef]

37. Lesjak, M.M.; Beara, I.N.; Orčić, D.Z.; Ristić, J.D.; Anačkov, G.T.; Božin, B.N.; Mimica-Dukić, N.M. Chemical characterization and biological effects of Juniperus foetidissima Willd. 1806. LWT Food Sci. Technol. 2013, 53, 530-539. [CrossRef]

38. Vourlioti-Arapi, F.; Michaelakis, A.; Evergetis, E.; Koliopoulos, G.; Haroutounian, S.A. Essential oils of indigenous in Greece six Juniperus taxa. Parasitol. Res. 2012, 110, 1829-1839. [CrossRef]

39. Emami, S.A.; Shahidi, N.H.; Hassanzadeh-Khayyat, M. Antioxidant activity of the essential oils of different parts of Juniperus sabina L. and Juniperus foetidissima Willd. (Cupressaceae). Int. J. Essent. Oil Ther. 2009, 3, 163-170.

40. Selaa, F.; Karapandzovaa, M.; Stefkova, G.; Cvetkovikja, I.; Trajkovska-Dokikjb, E.; Kaftandzievab, A.; Kulevanovaa, S. Antimicrobial activity of berries and leaves essential oils of Macedonian Juniperus foetidissima Willd. (Cupressaceae). Maced. Pharm. Bull. 2015, 61, 3-11. [CrossRef]

41. Salehi, S.P.; Mirza, M.; Calagari, M. Composition of the essential oils of Junipers (Juniperus foetidissima and J. oblonga) from Arasbaran Protected Area. J. Essent. Oil-Bear. Plants 2016, 19, 1261-1266. [CrossRef]

42. Babushok, V.I.; Linstrom, P.J.; Zenkevich, I.G. Retention indices for frequently reported compounds of plant essential oils. J. Phys. Chem. Ref. Data 2011, 40, 043101. [CrossRef]

43. Abdelwahed, A.; Hayder, N.; Kilani, S.; Mahmoud, A.; Chibani, J.; Hammami, M.; Chekir-Ghedira, L.; Ghedira, K. Chemical composition and antimicrobial activity of essential oils from Tunisian Pituranthos tortuosus (Coss.) Maire. Flavour. Fragr. J. 2006, 21, 129-133. [CrossRef]

44. The Pherobase Database and Semichemicals Home Page. Available online: http://www.pherobase.com/database/kovats/ kovatsdetailsulcatone.php (accessed on 27 November 2021).

45. NIST Webbook Home Page. Available online: http:/ / webbook.nist.gov / cgi / cbook.cgi?ID=C34995772\&Units=SI\&Mask=2680 (accessed on 27 November 2021).

46. Adams, R.P. Systematics of multi-seeded eastern hemisphere Juniperus based on leaf essential oils and RAPD DNA fingerprinting. Biochem. Pharmacol. 1999, 27, 709-725. [CrossRef]

47. Emami, S.A.; Asgary, S.; Naderi, G.A.; Shams Ardekani, M.R.; Kasher, T.; Aslani, S.; Airin, A.; Sahebkar, A. Antioxidant activities of Juniperus foetidissima essential oils against several oxidative systems. Braz. J. Pharmacogn. 2011, 21, 627-634. [CrossRef]

48. Ucar, G.; Balaban, M. The composition of volatile extractives from the wood of Juniperus excelsa, Juniperus foetidissima and Juniperus oxycedrus. Holz als Roh Werkstoff 2002, 60, 356-362. [CrossRef]

49. Tabanca, N.; Niogret, J.; Kendra, P.E.; Epsky, N.D. TLC-based bioassay to isolate kairomones from tea tree essential oil that attract male Mediterranean fruit flies, Ceratitis capitata (Wiedemann). Biomolecules 2020, 10, 683. [CrossRef]

50. Blythe, E.K.; Tabanca, N.; Demirci, B.; Kendra, P.E. Chemical composition of essential oil from Tetradenia riparia and its attractant activity for Mediterranean fruit fly, Ceratitis capitata. Nat. Prod. Commun. 2020, 15, 1-6. [CrossRef]

51. Stappen, I.; Wanner, J.; Tabanca, N.; Bernier, U.R.; Kendra, P.E. Blue tansy essential oil: Chemical composition, repellent activity against Aedes aegypti and attractant activity for Ceratitis capitata. Nat. Prod. Comm. 2021, 16, 1-8. [CrossRef] 
52. Tabanca, N.; Nalbantsoy, A.; Kendra, P.E.; Demirci, F.; Demirci, B. Chemical characterization and biological activity of mastic gum essential oils of Pistacia lentiscus var. chia from Turkey. Molecules 2020, 25, 2136. [CrossRef]

53. Nemeth, E.Z.; Nguyen, H.T. Thujone, a widely debated volatile compound: What do we know about it? Phytochem. Rev. 2020, 19, 405-423. [CrossRef]

54. Hendriks, H.; van der Elst, D.J.D.; van Putten, F.M.S.; Bos, R. The essential oil of Dutch Tansy (Tanacetum vulgare L.). J. Essent. Oil Res. 1990, 2, 155-162. [CrossRef]

55. Wedge, D.E.; Tabanca, N.; Sampson, B.J.; Werle, C.; Demirci, B.; Baser, K.H.C.; Nan, P.; Duan, J.; Liu, Z. Antifungal and insecticidal activity of two Juniperus essential oils. Nat. Prod. Commun. 2009, 4, 123-127. [CrossRef] [PubMed]

56. Carroll, J.F.; Tabanca, N.; Kramer, M.; Elejalde, N.M.; Wedge, D.E.; Bernier, U.R.; Coy, M.; Becnerl, J.J.; Demirci, B.; Baser, K.H.C.; et al. Essential oils of Cupressus funebris, Juniperus communis, and J. chinensis (Cupressaceae) as repellents against ticks (Acari: Ixodidae) and mosquitoes (Diptera: Culicidae) and as toxicants against mosquitoes. J. Vector Ecol. 2011, 36, $258-268$. [CrossRef] [PubMed]

57. Stappen, I.; Tabanca, N.; Ali, A.; Wedge, D.E.; Wanner, J.; Kaul, V.K.; Lal, B.; Jaitak, V.; Gochev, V.K.; Schmidt, E.; et al. Chemical composition and biological activity of essential oils from wild growing aromatic plant species of Skimmia laureola and Juniperus macropoda from western Himalaya. Nat. Prod. Commun. 2015, 10, 1071-1074. [CrossRef] [PubMed]

58. Zheljazkov, V.D.; Cantrell, C.L.; Semerdjieva, I.; Radoukova, T.; Stoyanova, A.; Maneva, V.; Kac`ániová, M.; Astatkie, T.; Borisova, D.; Dincheva, I.; et al. Essential oil composition and bioactivity of two Juniper species from Bulgaria and Slovakia. Molecules 2021, 26, 3659. [CrossRef] [PubMed]

59. Bonnot, N.C.; Morellet, N.; Hewison, A.J.M.; Martin, J.L.; Benhamou, S.; Simon Chamaillé-Jammes, S. Sitka black-tailed deer (Odocoileus hemionus sitkensis) adjust habitat selection and activity rhythm to the absence of predators. Can. J. Zool. 2016, 94, 385-394. [CrossRef]

60. Rojht, H.; Mesko, A.; Vidrih, M.; Trdan, S. Insecticidal activity of four different substances against larvae and adults of sycamore lace bug (Corythucha ciliata [Say], Heteroptera, Tingidae). Acta Agric. Slov. 2009, 93, 31-36. [CrossRef]

61. Lee, S.; Tsao, R.; Peterson, C.; Coats, J.R. Insecticidal activity of monoterpenoids to western corn rootworm (Coleoptera: Chrysomelidae), two spotted spider mite (Acari: Tetranychidae), and house fly (Diptera: Muscidae). J. Econ. Entomol. 1997, 90, 883-892. [CrossRef] [PubMed]

62. Wróblewska-Kurdyk, A.; Gniłka, R.; Dancewicz, K.; Grudniewska, A.; Wawrzeńczyk, V.; Gabryś, B. $\beta$-Thujone and its derivatives modify the probing behavior of the peach potato aphid. Molecules 2019, 24, 1847. [CrossRef] [PubMed]

63. Flath, R.A.; Cunningham, R.T.; Mon, T.R.; John, J.O. Additional male Mediterranean fruit fly (Ceratitis capitata Wied.) attractants from Angelica seed oil (Angelica archangelica L.). J. Chem. Ecol. 1994, 20, 1969-1984. [CrossRef] [PubMed]

64. Kendra, P.E.; Owens, D.R.; Montgomery, W.S.; Narvaez, T.I.; Bauchan, G.R.; Schnell, E.Q.; Tabanca, N.; Carrillo, D. $\alpha$-Copaene is an attractant, synergistic with quercivorol, for improved detection of Euwallacea nr. fornicatus (Coleoptera: Curculionidae: Scolytinae). PLoS ONE 2017, 12, e0179416.

65. Dambolena, J.S.; Zunino, M.P.; Herrera, J.M.; Pizzolitto, R.P.; Areco, V.A.; Zygadlo, J.A. Terpenes: Natural products for controlling insects of importance to human health-A structure-activity relationship study. Psyche 2016, 17, 4595823. [CrossRef]

66. Langsi, J.D.; Nukenine, E.N.; Oumarou, K.M.; Moktar, H.; Fokunang, C.N.; Mbata, G.N. Evaluation of the insecticidal activities of $\alpha$-pinene and 3-carene on Sitophilus zeamais Motschulsky (Coleoptera: Curculionidae). Insects 2020, 11, 540. [CrossRef]

67. Xie, F.; Rizvi, S.A.H. Fumigant toxicity and biochemical properties of $(\alpha+\beta)$ thujone and 1,8-cineole derived from Seriphidium brevifolium volatile oil against the red imported fire ant Solenopsis invicta (Hymenoptera: Formicidae). Rev. Bras. Farmacogn. 2019, 29, 720-727. [CrossRef]

68. Council of Europe. European Pharmacopoeia, 5th ed.; Council of Europe: Strasbourg, France, 2005; Volume 1, p. 217.

69. Tumen, I.; Hafizoglu, H.; Pranovich, A.; Reunanen, M. Chemical constituents of cones and leaves of Cypress (Cupressus sempervirens L.) grown in Turkey. Fresenius Environ. Bull. 2010, 19, 2268-2276.

70. Tumen, I.; Reunanen, M. A Comparative study on turpentine oils of oleoresins of Pinus sylvestris L. from three districts of Denizli. Rec. Nat. Prod. 2010, 4, 224-229.

71. Van den Dool, H.; Kratz, P.D. A generalization of the retention index system including linear temperature programmed gas-liquid partition chromatography. J. Chromatogr. 1963, 11, 463-471. [CrossRef]

72. Joulain, D.; Koenig, W.A. The Atlas of Spectra Data of Sesquiterpene Hydrocarbons; Verlag: Hamburg, Germany, 1998.

73. McLafferty, F.W.; Stauffer, D.B. The Wiley/NBS Registry of Mass Spectral Data; Wiley and Sons: New York, NY, USA, 1989.

74. Hochmuth, D.H. MassFinder 4.0; Hochmuth Scientific Consulting: Hamburg, Germany, 2008.

75. Systat Software. SigmaPlot for Windows, 14.0; Systat Software, Inc.: San Jose, CA, USA, 2017.

76. Abbott, A.F. A method of computing the effectiveness of an insecticide. J. Econ. Entomol. 1925, 18, 265-267. [CrossRef]

77. SAS Institute. SAS/STAT, 9.4; SAS Institute: Cary, NC, USA, 2020. 